\section{Kastamonu Eğitim Dergisi Kastamonu Education Journal}

Ocak 2019 Cilt:27 Sayı:1

kefdergi.kastamonu.edu.tr
Başvuru Tarihi/Received: 28.06.2018

Kabul Tarihi/Accepted: 10.07 .2018

DOI: $10.24106 /$ kefdergi.3195

\title{
Matematik Bir Bilim Dalı Mıdır? Matematik Öğretmen Adaylarının Bilim- Matematik İlişkisine Dair Algıları ${ }^{1}$
}

\section{Is Mathematics A Science Branch? Mathematics Teacher Candidates' Perceptions Of Science And Mathematics}

\section{Öz}

\author{
Hüseyin EŞ², Atilla ÖZDEMiR ${ }^{3}$, Makbule KAPLAN ${ }^{4}$
}

Bilimsel ve teknolojik gelişmelerin insanlığa sağladığı kazanımlar bilimi toplumsal hayatımızın önemli bir parçası haline getirmektedir. Ancak günümüz toplumunda bu kadar önemli bir yere sahip olan bilim kavramını tanımlamak hangi alanın bilimin sınırları içerisinde hangisinin ise dışında kaldığını belirtmek çok da kolay görünmemektedir. Günlük yaşantımızdan bilimsel ve teknolojik çalışmalara kadar pek çok alanda kullandığımız ve vazgeçilmezimiz olan matematiğin gerçekte bir bilim olup olmadığı ise üzerinde tartışılan bir konudur. Bu çalışmada bu konu üzerinde durulmuş ve Matematik öğretmen adaylarının genel anlamda bilim ve matematiğe dair algılarının, söz konusu algıların ışığında oluşmuş bilim - matematik ilişkisine dair düşünceleri inceleme konusu yapılmıştır. Araştırmanın çalışma grubunun belirlenmesi, veri toplama kaynakları ve verilerin analizi süreçlerinde nitel metodoloji esas alınmıştır. Çalışma grubunda bir devlet üniversitesinin eğitim fakültesinde öğrenim görmekte olan 38 (20 erkek, 18 kız) matematik öğretmen adayı bulunmaktadır. Araştırmanın verilerini toplamak amacıyla araştırmacılar tarafindan geliştirilen ve yedi açık uçlu sorudan oluşan Bilim-Matematik Algısı Formu (BMAF) kullanılmıştır. Araştırmada ulaşılan veriler içerik analizi ile nitel metodolojiye uygun olarak analiz edilmiştir. Araştırma bulguları incelendiğinde katilımcıların bilim ile teknoloji arasındaki ayrımı net olarak yapamadıkları, bilimsel yöntemi açıklarken bilimsel bilgiye ulaştıran tek bir hiyerarşik yolu ifade etmeye çalıştıkları, matematiksel bilgi üretim sürecini problem çözümü ve ispat süreci olarak değerlendirdikleri ve önemli bir kısmının matematiği bir bilim dalı, bir kısmının ise bilime yardımcı bir alan olarak değerlendirdikleri görülmüştür.

Anahtar Kelimeler: Bilim ve matematik, bilimin doğası, matematiğin doğası, matematik öğretmen adayları

\section{Abstract}

The achievements that scientific and technological developments bring to humanity make science an important part of our social life. However, it is not so easy to define the concept of science which has such a significant place in contemporary society, and to specify which area is inside the boundaries of science and which is outside. It is, in fact, a matter of debate whether mathematics that we use in many areas from our daily lives to scientific and technological studies, and that is indispensable for us is actually a science or not. In this study, this subject was discussed and mathematics teacher candidates' perceptions of science and mathematics in general terms and their thoughts about the science-mathematics relationship that occurred in the light of these perceptions were analyzed. Qualitative methodology was taken as a basis in the determination of the study group, in the data collection resources and in the analysis of the data. The participants were 38 (20 male, 18 female) mathematics teacher candidates studying at the faculty of education of a state university in the study group. The Perception of Science and Mathematics Form (PSMF), which was developed by researchers and consists of seven open-ended questions, was used to collect the data of the study. Data obtained by open-ended questions were analysed with content analysis technique. When the research findings were examined, it was seen that participants cannot clearly distinguish between science and technology, they try to express a single hierarchical way of delivering scientific information while explaining the scientific method, they consider the mathematical knowledge production process as problem solving and proof process and a significant part of the participants considered the mathematics as a branch of science while some of them regarded it as an auxiliary field.

Keywords: Mathematics teacher candidates, nature of science, nature of mathematics, science and mathematics,

1. Bu çalışmanın bulgularının bir bölümü International Conference on Education in Mathematics, Science \& Technology (2018)'de sunulmuştur.

2. Sinop Üniversitesi Eğitim Fakültesi, Sinop, Türkiye; https://orcid.org/0000-0001-8294-5080

3. Sinop Üniversitesi Eğitim Fakültesi, Sinop, Türkiye; https://orcid.org/0000-0003-4775-4435

4. Sinop Üniversitesi Eğitim Fakültesi, Sinop, Türkiye; https://orcid.org/0000-0002-7962-702X

Atıf / Citation: Eş, H., Özdemir, A., \& Kaplan, M. (2019). Matematik bir bilim dalı mıdır? Matematik öğretmen adaylarının bilim-matematik ilişkisine dair algıları. Kastamonu Education Journal, 27(1), 407-419. doi:10.24106/kefdergi.3195 


\section{Extended Abstract}

Those who are trying to define mathematics often make themselves content with ordering some of its characteristics. However, these characteristics are usually not enough to understand what its nature is exactly like (Umay, 2002). While many researchers have expressed mathematics as a "language" (Karaçay, 1985; Yıldııım, 1996; King, 1998; Renyi, 2011), American Association for the Advancement of Science (AAAS) regards mathematics as the main language of science. The language of thinking logically, reasoning, problem-finding, solution-making and scientific laws. When we regard mathematics as a language, can we make reference to mathematical facts can be said to be in the sense that its concepts are meaningful for those who know their rules, but meaningless for those who have not learned them? Can we talk about mathematical facts when we regard mathematics as a language and when it is thought that it is meaningful for those who know its concepts and rules but meaningless and even non-existence for those who have not learned them? Even if we do not know newton's law of universal gravitation, it is inevitable that the materials we drop from the top are dropped. Does it describe a similar situation where we would have zero if we multiply zero with any number? This difference brings about the question, or rather the debate of "Is mathematics a science branch?". With mathematics being the language of science indisputably, is this sufficient for mathematics itself to be regarded as a science branch?

When the field literature was scrutinized; it was seen that studies that examine the perceptions of the preschool (Akerson, Buzzelli, \&Donelly, 2010; Turgut, Eş, Bozkurt Altan, \& Öztürk Geren, 2016), classroom (Tatar, Karakuyu, \& Tüysüz, 2011) and science (Turgut, 2009) teacher candidates and their perceptions were made. However, there were not enough studies that analyze neither the perceptions of mathematics teacher candidates related to science nor the relationship between science and mathematics. For this reason, in the present study, it was aimed to analyze the perceptions of mathematics teacher candidates about science and mathematics in general terms, and their thoughts of science-mathematics relationship which are shaped in the light of these perceptions.

\section{Method}

Qualitative methodology was taken as a basis for determining the study group and data collection resources, and during the analysis of data in this study where the perceptions of the mathematics teacher candidates about science and mathematics in general terms and their thoughts of science-mathematics relationship which are shaped in the light of these perceptions were regarded as the subject of this study.

The focus of the research is the relationship between science and mathematics. Therefore, the study group was formed from mathematics teacher candidates who would be the most important human factor in delivering mathematics to the community. In the study group, there were 38 (20 male, 18 female) mathematics teacher candidates who were studying in the education faculty of a state university during the 2017-2018 education year.

The Perception of Science and Mathematics Form (PSMF), which was developed by researchers and consists of seven open-ended questions, was used to collect the data of the study. It was aimed to examine the candidates' general sense of science with the first two questions in the PSMF, their mathematics perception in the general sense with the third and fourth questions, and their thoughts of science - mathematics relationship with the last three questions.

Data obtained by open-ended questions were analysed with content analysis technique.

\section{Findings}

When the findings of the research were examined, it was seen that the participants emphasize technology the most while defining science and referring to its purposes, and they think that science has the mission of facilitating the life. Additionally, it was observed that while describing the scientific method a significant portion of the participants tried to depict a single set of fixed steps that scientists always follow, a single hierarchical way of delivering scientific knowledge to them without a doubt. The Scientific Method myth, by pointing out a hierarchical relationship between theory and law, also reveals a common misconception in this area. While defining mathematics, participants brought language into the forefront most, and then information source, thinking style, culture, science and game concepts respectively.

When the findings constituting the focus of this research regarding the perceptions of mathematics teacher candidates about the science-mathematics relationship are evaluated, it is seen that a significant part of the candidates considers mathematics as a science branch. Even though this finding seems to be contradictory to other findings of the research in the first place (such as not using the concept of "science" in their definitions, etc.), the contradiction emerges when the answers of the participants are analysed. That is because most of the candidates who have expressed mathematics as a science branch have pointed out the abstraction of mathematics at the same time. While some of the candidates express mathematics as an auxiliary branch to science in the mathematics-science relationship, others consider it as two areas that are affected by each other. In addition to these, a few of the candidates have seen mathematics over the top of all sciences, emphasizing the influence of mathematics on science and creating a hierarchy.

In conclusion, it is seen that science perceptions of mathematics teacher candidates are shaped on some misunderstandings. This situation is also reflected in the candidates' science-mathematical relationship and causes the candidates to experience difficulties in describing what mathematics is, which they will be teaching, and how it is related to science. 


\section{Giriş}

Günlük yaşantımızdan bilimsel ve teknolojik çalışmalara kadar pek çok alanda kullandığımız ve vazgeçilmezimiz olan matematik nedir? Umay’a (2002) göre tanımlanması en zor kavramlardan biridir. Toluk'a (2003) göre ise "sayı ve şekil bilgisi", "işlemler ve kurallar topluluğu", "desenler ve düzenler bilimi" gibi değişik tanımlamalar ile ifade edilebilir. Türk Dil Kurumu (TDK) ise matematiği aritmetik, cebir, geometri gibi sayı ve ölçü temeline dayanarak niceliklerin özelliklerini inceleyen bilimlerin ortak adı olarak tanımlamaktadır.

Matematiği tanımlamaya çalışanlar genellikle onun bazı özelliklerini sıralamakla yetinmişlerdir. Ancak bu özellikler genellikle onun doğasının, tam olarak ne olup ne olmadığının anlaşılması için yeterli değildir (Umay, 2002). Pek çok araştırmacı matematiği bir "dil" olarak ifade etmekte iken (King, 1998; Renyi, 2011; Yıldırım, 1996; Karaçay, 1985) Amerika Fen Bilimleri Geliştirme Kurumu (AAAS) matematiği bilimin ana dili olarak görmektedir. Mantıklı düşünmenin, akıl yürütmenin, problemleri saptamanın, çözüm üretmenin ve bilimsel yasaların dili. Matematiği bir dil olarak kabul ettiğimizde, onun kavramlarını, kurallarını bilenler için anlamlı fakat öğrenmemiş olanlar için ise anlamsız hatta yok hükmünde olacağı düşünüldüğünde acaba matematiksel gerçeklerden söz edilebilir mi? Kütle çekim yasasını bilmesek dahi yüksekten bıraktığımız maddelerin yere düşmesi kaçınılmaz bir durum iken sıfir ile herhangi bir sayıyı çarptığımızda sonucun sıfir olacağı benzer bir durumu betimler mi? Bu farklılık matematik bir bilim dalı mıdır? sorusunu daha doğrusu tartş̧masını gündeme getirmektedir. Matematiğin bilimin dili olduğu tartş̧ma götürmez bir durum olmakla birlikte acaba bu durum, matematiğin kendisinin de bir bilim dalı olarak kabul edilmesi için yeterli midir? Bu soruyu yanıtlayabilmek için elbette öncelikli olarak "bilim nedir?" sorusunu yanıtlamak gerekmektedir. Bilim de matematiğe benzer şekilde toplumsal yaşantımızın vazgeçilmez unsurlarından biri haline gelmiştir. Öyle ki bilimin görüşü olmadan insani değerlerin, politik ve ekonomik sorunların veya eğitimin amaçlarının dahi tartşılamayacağı iddia edilmektedir (Hurd, 1998). Ancak günümüz toplumunda bu kadar önemli bir yere sahip olan bilim kavramını tanımlamak çok da kolay görünmemektedir. Mesela Feder (2014), bilimi güvenilir bir biçimde bilgiye ulaşma teknikleri olarak ifade ederken McComas'a (1996) göre bilim, doğal dünyayla ilgili soruları cevaplamak üzere bilimsel araştrrma yöntemlerini kullanarak herkesin irdelemesine açık, geçerli ve güvenilir genellemeler ve açıklamalar ortaya koyma etkinliğidir. Kuhn'a (2006) göre ise bilim, süreklilik göstermez, belirli bir istikrarı yoktur ve hâkim değerler dizisi doğrultusunda olağan biçimde devam ederken zaman zaman gerçekleşen devrimlerle kesintiye uğrar. Hâkim değerler dizisi yerini bir başkasına bırakır ve devrimle gelen bilim yeni olağan bilim halini alır. Eş (2014) ise farklı bilim alanlarının aynı kavramı dahi farklı şekillerde (tanımlama, sınıflama gibi) ele alabileceğini belirtmektedir. Burada sadece Feder'in (2014) tanımı dikkate alındığında Matematik de güvenilir bir biçimde bilgiye ulaşma tekniğidir. Bu bağlamda Matematik bir bilim dalı olarak kabul edilebilir. Ancak McComas'ın (1996) doğal dünya vurgusu Matematiği bilimin bir miktar dışına itmektedir. Benzer şekilde Kuhn'un (2006) bilimsel devrimler görüşü Matematiğin aksiyomatik yapısı ile tam bir uyum göstermemektedir. Öyle ki Umay (2002b) hiçbir fonksiyonun türevinin alınamayacağı kanıtlansa bile yapılmış olan ispatın ortadan kalkmayacağını, olsa olsa uygulama alanı olmadığından kullanılamayacağını ifade etmektedir. Eş (2014) birbirine çok yakın olan beslenme ve biyoloji gibi iki bilim dalının dahi aynı kavramı farklı ele aldıklarını belirtmektedir. Matematik için ise örneğin Geometri ve Cebir'in aynı kavramı farklı değerlendirme durumu söz konusu değildir. Ayrıca bilimi basit bir şekilde tasvir etmek ya da bilimin sınırlarını çok keskin bir şekilde çizmek pek de mümkün görülmemektedir. Mesela iğnelerin deri içine sokulması ile vücuttaki spesifik noktaların uyarılması olarak tanımlanan akupunktur (Sjölund, 2005), önceden sözde-bilim olarak kabul edilirken (Allchin, 1996), yapılan kontrollü deneylerin ardından sınırlı da olsa bilimsel kabul görebilmektedir (Jones, 2002). Bununla birlikte gökcisimlerinin insan psikolojisi ve kişiliği üzerindeki etkilerinden dem vuran ve astronomi ile psikoloji bilimlerinin görevlerine talip olan bir sözde-bilim olan astrolojiyi bilim olarak kabul eden çevreler de varlığını korumaya devam etmektedir (Francis ve Robbins, 2007; Lundström, 2007; Losh ve Nzekwe, 2011). Matematiğin sınırları ile ilgili benzer tartışmalar ise yok denecek kadar azdır.

Bilime atfedilen değer, başka bir ifadeyle bilimin güvenilir tek bilme biçimi (din, felsefe, sanat vb. ötesinde) olduğu düşüncesi, her değerli şeyin başına gelenin bilimin de başına gelmesine neden olmuş pek çok çalışma alanı bir şekilde kendisini bilim içerisinde ya da çevresinde (yakın ilişki durumunda) konumlandırma çabası içerisine girmiştir. Bu durum ise neyin bilim olup olmadığını, bilimin sınırlarını çizmeyi hem zorunlu hem de zor bir durum haline getirmektedir.

AAAS matematiği hem teorik hem de uygulamalı bir bilim olarak değerlendirmekte ve matematik ile bilim arasındaki ittifakın yüzyıllar öncesine uzanan derin bir geçmişe sahip olduğunu belirtmektedir. Öyle ki Platon, Akademisinin girişine "geometri bilmeyen giremez" yazdırmıştır. Bu ittifakta bilim, araştırmak için matematiğe ilginç problemler sağlarken matematik ise verilerin analizinde kullanılacak güçlü araçlarla bilimi desteklemektedir. Bilim insanı dendiğinde ilk akla gelen isimlerden biri olan Isaac Newton Fizik biliminin belki de çağ atlamasına sebep olan Matematik alanındaki önemli buluşun "fluxions" (diferansiyel hesap) da sahibidir. Matematik alanındaki bu buluş sayesinde Newton mekaniği an- 
lamlı, anlatılabilir ve de anlaşılabilir hale gelmiştir. Bir diğer önemli bilim insanı Einstein ise bilimi matematik sayesinde gözlemlerin ötesine taşımıştır. Öte yandan Matematik ile bilim anlaşılabilir bir düzenin varlığına olan inanç, mantıksal düşünmenin kullanımı, dürüstlük ve açıkık gibi ilkelere sahip vb. ortak özelliklere sahiptirler (AAAS, 1989). Ancak Yıldırım (2005) ise matematik ile ampirik bilimleri ayıran en önemli özelliği, ulaştı̆ı sonuçların kesin zorunlu olması olarak belirtmektedir. Diğer bir ifadeyle hiçbir olgusal genelleme ya da hipotez, ne denli belgelenmiş olursa olsun, yeni gözlem verileri karşısında yanlış çıkma olasılı̆ından kurtulmuş olamaz. Oysa matematikte bir teorem bir kez ispat edildi mi artık, aksiyomları reddedilmedikçe, yanlış çıkma olasılığı yoktur. Çoğu insan bilim kavramını yalnızca fizik, kimya ve biyolojiyi düşünerek doğa bilimleri anlamında kullanmaktadır. Bu anlamıyla bakıldığında doğal bilimler fiziksel evreni araştrrırken matematik bunu araştırmaz bu yüzden gerçekten bir doğal bilim değildir (Ainsley, 1990). Öte yandan birçok matematikçi de kendisini bilim insanı olarak görmezler (Growney, 1992). Özellikle Platoncu görüşe dayalı olan matematiksel nesnelerin fiziksel dünyadan bağımsız var olduğu düşüncesi matematik dünyasında etkili olmuştur. Bu görüşün bir diğer önemli savı matematiğin apriori (duyumlardan bağımsız) olduğu yani deneysel olmadığıdır. Duyumlar aracılığıyla elde edilen ampirik bilginin aksine matematiksel gerçekler ve nesneler "zihnin gözü" aracılığıyla sezilirler böylece görmeden kavranırlar. Bu görüşün etkileri karşımıza matematik tarihinden okullarda öğretilen matematiğe kadar birçok alanda karşımıza çıkmaktadır (Kuryel, 2010). Buna karşın bilginin anlamlandırılmasının matematiğin insanlık tarihiyle gelişimi düşünüldüğünde mümkün olabileceğini savunan bazı bilim insanlarına göre ise bir çocuk saymayı öğrenirken öncelikle çakılları ve küçük dalları sayarak başlar. Ancak beş çakıl taşı ve dört çakılın toplandığında dokuz ettiğini öğrendikten sonra beş art dördün dokuz ettiğini öğrenir. Böylece matematiğin aslında doğadaki bilgiden ve duyulardan bağımsız olmadığı görülür (Renyi, 2011). Bu iki farklı görüşü Einstein;

\section{"Matematiksel bir önerme olgusal dünyaya ilişkin olduğu kadarı ile kesin değildir; kesin olduğu kadarı ile} olgusal dünyaya iliş̧kin değildir."

sözü ile önemli ölçüde derlemiş ve açıklık getirmiştir. Yani bilim doğası gereği olgusal dünya ile ilgilenir, onu açıklamaya çalışır ve hiçbir bilimsel bilgi kesin değildir.

Alan yazın incelendiğinde; okulöncesi (Akerson, Buzzelli, \& Donelly, 2010; Turgut, Eş, Bozkurt Altan, \& Öztürk Geren, 2016), sınıf (Tatar, Karakuyu, \& Tüysüz, 2011) ve fen bilgisi (Turgut, 2009) öğretmen adayları ile adayların bilime ilişkin algılarını inceleyen çalışmaların yapıldığı görülmektedir. Ancak gerek matematik öğretmen adaylarının bilime ilişkin algılarını inceleyen gerekse de bilim ile matematik ilişkisini irdeleyen yeterli sayıda çalışmaya rastlanmamıştı. Bu gerekçelerle mevcut çalışmada matematik öğretmen adaylarının genel anlamda bilim ve matematiğe dair algılarının, söz konusu algıların doğrultusunda şekillenen bilim - matematik ilişkisine dair düşüncelerinin incelenmesi amaçlanmaktadır.

\section{Yöntem}

Matematik öğretmen adaylarının genel anlamda bilim ve matematiğe dair algılarının, söz konusu algıların ışığında oluşmuş bilim - matematik ilişkisine dair düşüncelerinin inceleme konusu yapıldığı bu çalışmada çalışma grubunun belirlenmesi, veri toplama kaynakları ve verilerin analizi süreçlerinde nitel metodoloji esas alınmıştr. Çünkü nitel araştırmalar, insanların dünyalarını nasıl oluşturdukları, bu dünyada edindikleri deneyimi nasıl yorumladıkları ve anlamlandırdıkları ile ilgilenirler ve nitel araştırmaların ürünü zengin bir betimlemedir (Merriam, 2013). Bu bağlamda çalışma grubunun nasıl belirlendiği, veri toplama araçlarının nasıl hazırlanıp uygulandığı ve verilerin nasıl analiz edildiği detaylıca açıklanarak ayrı başıılar halinde sunulmuştur.

\section{3. Çalışma Grubu}

Araştırmanın çalışma grubu, çalışmanın amacı ve esas alınan nitel metodoloji uyarınca amaçlı çalışma gruplarından uygun durum çalışma grubu olarak seçilmiştir. Böylece araştırmanın amacına uygun ve kolay araştırma yapılacak kişi ve grupların belirlenmesi amaçlanmıştı (Creswell, 2012; Sönmez \& Alacapınar, 2016). Araştırmanın odak noktasını bilim - matematik ilişkisi oluşturmaktadır. Bu nedenle araştırmanın çalışma grubu matematiğin topluma ulaştrılmasında en önemli insan faktörü olacak olan matematik öğretmen adaylarından oluşturulmuştur. Çalışma grubunda bir devlet üniversitesinin eğitim fakültesinde 2017-2018 eğitim öğretim yılında öğrenim görmekte olan 38 (20 erkek, 18 kız) matematik öğretmen adayı bulunmaktadır. Söz konusu öğretmen adaylarının tamamı araştırmaya gönüllülük esasına dayalı olarak katıımışardır.

\section{Veri Toplama Aracı}

Araştırmanın verilerini toplamak amacıyla araştırmacılar tarafindan geliştirilen ve yedi açık uçlu sorudan oluşan 
Bilim-Matematik Algısı Formu (BMAF) kullanılmıştr. BMAF de yer alan ilk iki soru ile adaylarının genel anlamda bilim algısı, üçüncü ve dördüncü sorular ile genel anlamda matematik algısı, son üç soru ile de bilim - matematik ilişkisine dair düşüncelerinin incelenmesi amaçlanmıştır. BMAF'nin geliştirilme sürecinde Şekil 1. deki yol haritası izlenmiştir (Büyüköztürk, 2005);

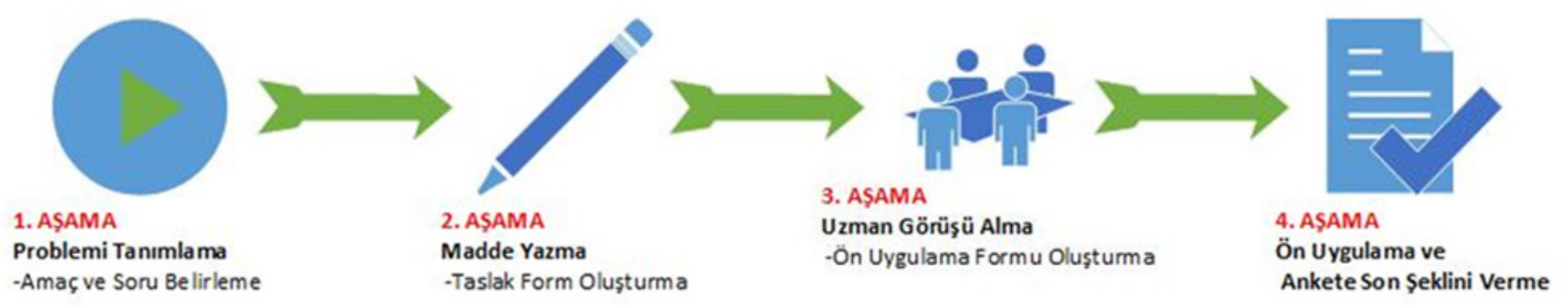

\section{Şekil 1. BMAF'ın Geliştirilme Süreci}

1. Problemin Tanımlanması: Bu çalışmanın amacı matematik öğretmen adaylarının "bilim - matematik ilişkisine dair düşüncelerinin belirlenmesidir. Dolayısıyla hazırlanan formun bu soruya cevap verecek şekilde olması amaçlanmıştr. Bu amaca uygun olarak öğretmen adaylarının öncelikle bilim ve matematik ile algılarını ve bu algılar ışığında oluşan bilim - matematik ilişkisi ile ilgili düşüncelerinin belirleneceği formun hazırlanması planlanmıştır.

2. Madde yazma: bu basamakta araştırmanın amacı doğrultusunda öncelikli olarak ilgili alan yazın taranmıştır. Yapılan taramada araştırmanın amacıyla tam olarak örtüşen bir çalışmaya rastlanmamıştır. Ancak öğrenci ve öğretmen adaylarının bilim algılarına yönelik çalışmalara rastlanmış (Frykholm ve Glasson, 2005; Berber \& Güzel, 2009; Turgut, 2010; Şenel \& Aslan, 2014; Turgut, Öztürk \& Eş, 2017) ve bu çalışmalar incelenmiştir. Formu oluşturan maddelerin yazımında, öğretmen adaylarının serbestçe cevap vermelerini sağlamak, beklenilmeyen ya da planlanamayan cevapların da alınabilmesi ve böylece konu hakkında daha geniş ve ayrıntılı bilgiye sahip olunabilmesi amacıyla açık uçlu yorumlama soruları tercih edilmiştir. Formda yer verilen yedi açık uçlu sorunun ilk ikisi ile öğretmen adaylarının genel anlamda bilim algııının tespit edilmesi, üçüncü ve dördüncü sorular ile öğretmen adaylarının genel anlamda matematik algısının tespit edilmesi amaçlanmıştır. Beş, altı ve yedinci sorular ile de adayların bilim - matematik ilişkisi ile ilgili düşüncelerinin belirlenmesi amaçlanmıştır.

3. Uzman Görüşü Alma: Bu aşamada formda yer alan maddelerin ihtiyaç duyulan olgusal ve yargısal verileri kapsamada ve toplamada ne derece yeterli olduğunu belirlemek amacıyla sırasıyla Fen eğitimi, Matematik eğitimi ve ölçme ve değerlendirme alanlarında çalışmaları olan 3 uzmanın görüşü alınmıştır. Uzmanların ilgili maddeler ile ilgili olumlu görüşlerinin alınmasının ardından son aşamaya geçilmiştir.

4. Ön Uygulama, Analizler ve Ankete Son Şeklini Verme: Bu aşamada taslak form araştırmanın dışında tutulmuş aynı programda öğrenim görmekte olan 12 öğrenciye araştırmacılar tarafindan uygulanarak gelen eleştiriler doğrultusunda forma son hali verilmiştir. Bu öğrencilerin cinsiyete göre eşit dağılım göstermesine de dikkat edilmiştir. Elde edilen bilgiler sonucunda form nihai uygulama için hazır hale getirilerek, geçerli ve güvenilir bir form elde edilmiştir (Mertens, 1998).

\section{Veri Analizi}

Araştırmada ulaşılan veriler içerik analizi ile nitel metodolojiye uygun olarak analiz edilmiştir. Söz konusu analiz sürecinde, her bir katılımcının formda yer alan sorulara verdiği cevaplar kendi içindeki bütünlüğünü bozmadan ve özellikle tekrarlanan kavramların, ifadelerin karşılaştırmalı olarak değerlendirilmesine izin verecek şekilde gözden geçirilmiştir. Bu şekilde daha sağlıklı ve geçerli bir kodlama sisteminin oluşturulabileceği düşünülmüştür. İlgili süreçte önce adayların cevap kâğıtları temsili olarak yeniden adlandırımış (mesela ilk öğretmen adayının kâğıdı için ÖA1 gibi) ve her bir cevap kâğıdı ayrı ayrı okunarak tespit edilen potansiyel kavramlar, tematik yapılar kısaca kodlanmıştır. Kodlama bazen kelimeler, bazen de bütün olarak cümleler veya paragraflar bazında yapıımış ve ana fikirler, temalar üzerinden gerçekleştirilmiş, böylece oluşturulan ilk kodlar listesi benzer yapıların yeniden adlandırılması yoluyla sadeleştirilmiş ve nihai halini almıştı (Gay, Mills ve Airasian, 2006; Bogdan, Biklen, 2007). Kodlar listesi iki araştırmacı tarafindan ayrı ayrı yapılmış çıkarılan kodlardaki benzerlik ve farklılıklar tespit edilmiştir. Farklı kodlamalar tekrar gözden geçirilerek gereken durumlarda öğretmen adaylarının cevabında anlatılmak istenen husus ile ilgili üçüncü bir uzmandan görüş alınmıştır. Adayların cevapları bu son kodlar listesine göre yeniden gözden geçirilmiş, oluşturulan kodların cevapları tam olarak karşıladığı kanısına ulaşıldıktan sonra ise ilgili frekansların belirlenmesi yoluna gidilmiştir. Analiz süreci, nihai listede 
yer alan ve verileri temsil ettiğine kani olunan kodların kendi içinde sınıflandırılarak belirli kategoriler altında gruplandırımasıyla sonlandırımıştır (Strauss ve Corbin, 1998; Creswell, 2005; Maxwell, 2005). Analizlerimizin güvenilirliği iki şekilde sağlanmıştır. Illk olarak, bu çalışma sırasında toplanan veriler, birinci ve ikinci yazarlar tarafindan bağımsız olarak kodlanmış, iki araştırmacı tarafindan oluşturulan kodlar karşılaştırılmış ve araştırmacıların çelişkiye düştüğü durumlar yeniden değerlendirilerek kodlara son şekli verilmiştir. Bu şekilde yapılan veri analizinin güvenirliği; [(Görüş birliği) / (Görüş birliği + Görüş ayrılığı)] x 100 formülü kullanılarak hesaplanmıştr (Miles \& Huberman, 1994). Kodlayıcılar arasındaki ortalama güvenirlik \% 94 olarak bulunmuştur. i̇kincisi, iki ayrı analiz karşılaştırıldıktan sonra oluşan kategori ve kod listesi gözlemci üçgenlemesi yöntemi (Denzin, 1970) ile süreci doğrulamak amacıyla araştırmaya katılmayan bir alan uzmanına inceletilmiştir. Söz konusu analiz sürecine dair örnek öğrenci ifadeleri ve oluşturulan kategori, kod ve örnek ifadeler Tablo 1'de sunulmuştur.

\section{Tablo 1. Örnek Kod ve ifadeler}

\begin{tabular}{|c|c|c|}
\hline Kategori & Kod & Örnek ifade \\
\hline \multirow{5}{*}{ Bilim algısı } & Teknoloji & "Bilimin amacı insanların ihtiyaçlarını karşılamaktır." \\
\hline & Evreni anlama & "Evreni ve dünyamızı algılayıp anlamamızı sağlayan uğraştır." \\
\hline & Bilgiye ulaşma yolu & "Bilgiye yani doğru ve tutarlı bilgiye ulaşma yolu" \\
\hline & Bilgi birikimi & "Çeşitli süreçler sonucunda ulaşılan bilgi birikimidir." \\
\hline & İnsanın kendini geliştirmesi & "Bilim insanın kendini geliştirmesi ve ... için yapılır" \\
\hline \multirow{5}{*}{$\begin{array}{l}\text { Bilimsel süreç } \\
\text { algısı }\end{array}$} & Tek yöntem miti & $\begin{array}{l}\text { "ilk olarak problemi tespit ederiz. Daha sonra bu problem hakkında gözlem yapar } \\
\text { ve veri toplarız. Hipotez kurup deneyler yaparız. Sonuç olumlu olursa teori, bu } \\
\text { ispatlanırsa da kanuna dönüşür." }\end{array}$ \\
\hline & Problem-süreç-kanıtlama & $\begin{array}{l}\text { "Önce bir problem ortaya çıkar, sonra bilimsel çalışmalar yapılarak problemin } \\
\text { çözümüne ulaşılır. En sonunda ise bu çözüm kanıtlanır." }\end{array}$ \\
\hline & Deney-gözlem & "Bilimsel süreçte deney ve gözlem kullanılır." \\
\hline & Problem-çözüm & "Insanlığın karşısına çıkan problemlere çözüm üretilir." \\
\hline & Farklı yöntemler & $\begin{array}{l}\text { "Tek bir yöntemden söz etmek doğru olmaz bu süreçte farklı yöntemler kullanıl- } \\
\text { maktadır..." }\end{array}$ \\
\hline \multirow{6}{*}{$\begin{array}{l}\text { Matematik } \\
\text { algısı }\end{array}$} & Dil & "Sağlam, kullanışlı, evrensel bir dil ve kültürdür." \\
\hline & Bilgi kaynağı & "İspat, teorem vb. den oluşan bilgi kaynağı" \\
\hline & Düşünme biçimi & "Sayıları, ispatları, teoremleri düşünme sanatıdır." \\
\hline & Kültür & “Matematik bir kültürdür." \\
\hline & Bilim dalı & "Her şeyden önce bir bilim dalıdır..." \\
\hline & Oyun & "... hayatın her alanında olan bir oyun gibidir..." \\
\hline \multirow{4}{*}{$\begin{array}{l}\text { Matematiğin } \\
\text { amacı }\end{array}$} & Doğayı ve yaşamı anlama & “... soyut kavramlar üzerinden doğayı ve yaşamı anlamak..." \\
\hline & Diğer alanları kolaylaştırma & "Farklı bilimsel alanlara hizmet eder..." \\
\hline & İnsanın kendini geliştirmesi & "Insanın özellikle zihinsel gelişiminde etkilidir..." \\
\hline & Günlük hayatı kolaylaştırma & "Alışveriş vb. günlük yaşantımızı kolaylaştırır ..." \\
\hline \multirow{4}{*}{$\begin{array}{l}\text { Matematiksel } \\
\text { süreç algısı }\end{array}$} & $\begin{array}{l}\text { Problem çözümü } \\
\text { İspat }\end{array}$ & $\begin{array}{l}\text { "Matematikte bilgi problem üzerine yoğunlaşarak, problemi çözerek üretilir." } \\
\text { "Matematik bir ispat sürecidir." }\end{array}$ \\
\hline & Zihinsel (soyut) faaliyet & “... zihnimizde soyutlaşttrarak bu bilgiyi üretir..." \\
\hline & Merak & "Matematiksel süreç merak ile başlar ..." \\
\hline & Birikimsel & "Mevcut bilgileri kullanıp yeni bilgiler üretilir." \\
\hline \multirow{4}{*}{$\begin{array}{l}\text { Bilim - mate- } \\
\text { matik algısı }\end{array}$} & Bilim dalı & "Matematikte bir bilimdir." \\
\hline & Bilime yardımcı & "FKB gibi bilim dallarının gelişmesinde önemlidir..." \\
\hline & Etkileşimli alanlar & "Matematik bilime ... yardım eder. Aynı şekilde bilme de matematiğe ..." \\
\hline & Tüm bilimlerin anası & "fizik, kimya, biyoloji tüm bilim dalları matematiğin alt dallarıdır" \\
\hline
\end{tabular}

\section{Katilımcıların Bilim Algısı}

BMAF'da yer alan birinci soruda katlımcılara "Bilim nedir ve ne amaçla yapılır?" sorusu yöneltilmiş ve bu soru ile katılımcılar genel anlamda bilim üzerinde düşünmeye sevk edilmiş ve bilimin kendileri için ne anlama geldiği, öncelikle bilimin hangi niteliklerini ön plana çıkarttkları tespit edilmeye çalışııış̧ır. Söz konusu soruya verilen cevapların analiziyle ulaşılan ve adayların bilimin temel özelliklerine dair algılarını temsil eden kodlar aşağıda Tablo 2'de sunulmuştur. 
Tablo 2. Katılımcıların Bilim Algıları

\begin{tabular}{llc}
\hline Kategori & Kod & $\mathrm{f}$ \\
\hline \multirow{3}{*}{ Bilim algısı } & Teknoloji & 30 \\
& Evreni anlama & 24 \\
& Bilgiye ulaşma yolu & 13 \\
& Bilgi birikimi & 5 \\
& İnsanın kendini geliştirmesi & 4 \\
\hline
\end{tabular}

Tablo 2 incelendiğinde kathlımcıların bilimi tanımlarken ve bilimin amaçlarından bahsederken en fazla teknolojiyi ön plana çıkardığı ve bilimin hayat/yaşamı kolaylaştırma misyonu olduğunu düşündüğü görülmüştür. Bu algı, bilim ile teknoloji arasındaki farkı muğlaklaştırmakta ve sorulara cevap bulma ve anlama uğraşı olmanın ötesinde bilime tasarım ve icat görevlerini yüklemektedir.

"Bilim bulunduğumuz dünyayı daha kolay yaşanılır hale getirmeyi amaçlar. Bilim evreni ve dünyamızı algılayıp anlamamızı sağlayan uğraştır (5)."

Örnek cevapta da görüldüğü gibi katılımcılar teknoloji vurgusunun ardından bilimin temel amacı olan evreni anlama gayretini de ön plana çıkartmaktadırlar. Örneğin ÖA17;

"evrendeki olayları ele alıp ... yasalara ulaşılan yol ..."

ifadesi ile bilimin evreni anlama gayretine vurgu yaparken aynı zamanda bunun bir süreç olduğunu da belirtmektedir. Benzer şekilde katılımcılar bilimin bir tür bilgiye ulaşma yolu ( $f=13$ ) olduğunu belirtmişlerdir. Bilimin süreç boyutuna ek olarak katılımcılar bilimin bir tür bilgi birikimi $(f=5)$ olduğu vurgusunu da yapmışlardır. Tüm bunlara ek olarak katılımcıların bir kısmı bilime hümanist bir bakış açısı ile yaklaşmış ve

"bilim insan doğasını geliştirmeye yarayan ... bir daldır (ÖA24)."

"ilim, ilim bilmektir, ilim kendin bilmektir (ÖA32)."

örnek ifadelerinde de görüldüğü üzere bilimin insanın kendini geliştirmesini sağlayan bir misyonunun da olduğuna işaret etmişlerdir.

BMAF'da yer alan ikinci soruda katılımcılara "bilimsel bilgi nasıl üretilir? Bilginin üretilme sürecini kısaca anlatınız." sorusu yöneltilmiş ve bu soru ile kattlımcıların bilimsel süreç ile ilgili algıları tespit edilmeye çalışılmıştır. Söz konusu soruya verilen cevapların analiziyle ulaşılan ve adayların bilimin temel özelliklerine dair algılarını temsil eden kodlar aşağıda Tablo 3'de sunulmuştur.

\section{Tablo 3. Katılımcıların Bilimsel Süreç Algısı}

\begin{tabular}{llc}
\hline Kategori & Kod & $\mathrm{n}$ \\
\hline & Tek yöntem miti & 16 \\
& Problem-süreç-kanıtlama & 9 \\
Bilimsel süreç algıSı & Deney-gözlem & 5 \\
& Problem-çözüm & 3 \\
& Farklı yöntemler & 1 \\
& Yanıt yok & 4 \\
\hline
\end{tabular}

Tablo 3 incelendiğinde kathlımcıların önemli bir kısmının $(n=16)$ bilimsel yöntemi tasvir ederken bilim insanlarının daima izlediği sabit bir adımlar kümesini, onları hiç şaşmadan bilimsel bilgiye ulaştıran tek bir hiyerarşik yolu ifade etmeye çalıştıkları görülmektedir;

"ilk olarak problemi tespit ederiz. Daha sonra bu problem hakkında gözlem yapar ve veri toplarız. Hipotez kurup deneyler yaparız. Sonuç olumlu olursa teori, bu ispatlanırsa da kanuna dönüşür."(ÖA32)

Örnek ifade de net bir şekilde ortaya konulan tek yöntem miti ayrıca teori ve kanun arasında hiyerarşik bir ilişkiyi de işaret ederek bu alanda sıkça rastlanan bir yanılgıуı da ortaya koymaktadır. Bununla birlikte katılımcıların bir bölümü $(n=9)$ bilimsel yöntemi, problem ile başlayan, ayrıntısını veremedikleri bir süreç ile devam eden ve kanıtlama ile sona eren bir süreç olarak ifade etmişlerdir. Bazı katılımcılar $(n=5)$ ise bilimsel yöntem ile ilgili olarak sadece deney ve gözlemi işaret ederken az sayıda katılımcı ( $n=3)$ bilimsel yöntemi problemlere çözüm getirme olarak ifade etmiştir. Bir katılımcı ise tek yöntem mitine karşı bir duruş sergileyerek bilimsel sürecin farklı yöntemler ile yürütülebileceğini belirtmiştir. Tüm bunlara ek olarak az sayıdaki katılımcı $(n=4)$ ise bilimsel yöntem ile ilgili herhangi bir yanıt vermekten kaçınmıştır. 


\section{Katılımcıların Matematik Algısı}

BMAF'da yer alan üçüncü soruda katılımcılara "Matematik nedir ve ne amaçla yapılır?" sorusu yöneltilmiş ve bu soru ile katlımcılar genel anlamda matematik üzerinde düşünmeye sevk edilmiş ve matematiğin kendileri için ne anlama geldiği, öncelikle matematiğin hangi niteliklerini ön plana çıkartthkları tespit edilmeye çalışılmıştı. Söz konusu soruya verilen cevapların analiziyle ulaşılan ve adayların matematiğin temel özelliklerine dair algılarını temsil eden kodlar Tablo 4'de, amacına dair düşüncelerini temsil eden kodlar ise Tablo 5'de sunulmuştur.

\section{Tablo 4. Katlımcıların Matematik Algısı}

\begin{tabular}{llc}
\hline Kategori & Kod & f \\
\hline & Dil & 13 \\
& Bilgi kaynağı & 11 \\
Matematik algısı & Düşünme biçimi & 9 \\
& Kültür & 5 \\
& Bilim dalı & 5 \\
& Oyun & 4 \\
\hline
\end{tabular}

Tablo 4 incelendiğinde katılımcıların "matematik nedir?" sorusunu yanıtlarken en fazla dil ( $f=13)$ sonrasında ise sırasıyla bilgi kaynağı ( $f=11)$, düşünme biçimi $(f=9)$, kültür $(f=5)$, bilim dalı $(f=5)$ ve oyun $(f=4)$ kavramlarını ön plana çıkarttkları görülmektedir.

Tablo 5. Katılımcıların Matematiğin Amacı İle İlgili Düşünceleri

\begin{tabular}{llc}
\hline Kategori & Kod & $\mathrm{f}$ \\
\hline \multirow{4}{*}{ Matematiğin amacı } & Doğayı ve yaşamı anlama & 17 \\
& Diğer alanları kolaylaştırma & 13 \\
& İnsanın kendini geliştirmesi & 9 \\
& Günlük hayat kolaylaştırma & 6 \\
\hline
\end{tabular}

Tablo ... incelendiğinde katılımcıların matematiğin amaçları arasında en fazla doğayı ve yaşama anlama gayretini ( $f=17$ ) ön plana çıkarttkları görülmektedir;

"...matematiğin amacı soyut kavramları anlayarak doğayı ve yaşamı anlayabilmektir (ÖA2)."

"matematik Tanrı'nın evreni anlattı̆ı formüldür. Matematik hayatı anlama çabasıdır (ÖA9)."

Örnek ifadelerde de görüldüğü üzere adayların bir bölümü matematiğin soyut yapısına vurgu yapmakla birlikte matematiğe doğayı ve yaşama anlama misyonu da vererek bilim-matematik ilişkisini muğlaklaştırmaktadır. Bununla birlikte adayların bir bölümü ise matematiğin amacının diğer alanların işleyişini kolaylaştırmak $(f=13)$ olduğunu ifade etmektedir;

"...matematik bilime katkı sağlar ve bu katkı ile teknolojinin gelişmesini sağlar (ÖA5)."

Örnek ifade de matematik ile bilim ve teknolojinin ayrı şekilde dile getirilmesi önemli bir bulgudur. Öğretmen adayları matematiğin amaçları arasında insanın kendini geliştirmesi $(f=9)$ ve günlük hayat kolaylaştırmayı $(f=6)$ ifade etmişlerdir;

"matematik insan zihnini geliştiren bir alandır. Insan zihnini geliştirerek matematikte ve günlük hayatta karşısına çıkan problemleri çözmede işe yarar (ÖA20)."

Öğretmen adaylarının genel anlamda matematik ve matematiğin amaçları ile ilgili düşüncelerini irdeleyen üçüncü sorunun ardından adaylara BMAF'da yer alan dördüncü soru ile "Matematikte bilgi nasıl üretilir?" sorusu yöneltilmiş ve bu soru ile adayların matematiğin bilgi üretim süreci ile ilgili algıları tespit edilmeye çalışılmıştır. Söz konusu soruya verilen cevapların analiziyle ulaşılan ve adayların matematiksel bilgi üretim sürecine dair algılarını temsil eden kodlar aşağıda Tablo 6'da sunulmuştur. 
Tablo 6. Adayların Matematiksel Bilgi Üretim Süreci Algıları

\begin{tabular}{llc}
\hline Kategori & Kod & $\mathrm{f}$ \\
\hline & Problem çözümü & 21 \\
& İspat & 19 \\
Matematiksel süreç algısı & Zihinsel (soyut) faaliyet & 9 \\
& Merak & 5 \\
& Birikimsel & 2 \\
\hline
\end{tabular}

Tablo 6 incelendiğinde adayların matematiksel bilgi üretim sürecini anlatırken en fazla problem çözümüne $(\mathrm{f}=21)$ vurgu yaptkları görülmektedir.

“... matematiksel bilgi matematikçilerin bir problem ile karşıllaşıp çözüm üretmeye yönelmesi ile üretilir (ÖA7)."

Örnek ifadede görüldüğü gibi adayların bir bölümü $(f=15)$ matematiksel bilginin yine matematik ile ilgili problemler ile karşılaşılması sonucu üretildiği düşüncesini ortaya koyarken bazı adaylar $(\mathrm{f}=6)$ ise;

"insanların günlük yaşamdaki problemler ile karşılaşması ve merak sonucu matematiksel bilgi üretilir (ÖA14)."

örnek ifadesinde görüldüğü üzere matematiksel bilginin üretimini günlük yaşamdaki problemler ile ilişkilendirmektedir. Ayrıca bilgi üretim süreci bazı adaylar $(\mathrm{f}=5)$ tarafindan merak duygusu ile de ilişkilendirilmektedir. Adaylar bilgi üretim sürecinde problem çözümünün ardından en fazla ispat $(f=19)$ kavramını vurgulamışlardır. İspat kavramını belirten adayların ifadeleri incelendiğinde aşağıdaki örneklerde de görüleceği üzere iki durumun ortaya çıktı̆̆ görülmektedir. Birincisi adaylar en fazla yeni bir problemin çözümü $(f=15)$ için ispat sürecini ifade ederken bir kısmı $(f=4)$ ise mevcut bilginin ispatnı ifade etmektedir.

“...bir sonraki adım düşünülerek yeni problemler üretilir, ispatları yapılır(ÖA27).”

"... ilk önce açıklanamayan bir bilgi bulunur ve ispat yapılır (ÖA19)."

Öğretmen adaylarının bir bölümü ( $f=9$ ) matematiksel bilgi üretim sürecinin zihinsel (soyut) bir süreç olduğuna da işaret etmişlerdir;

"matematikte evrendeki olayları doğa olaylarını açıklayarak bilgi elde ederiz. Gerçek dünyadan esinlenip bunu zihnimizde soyutlaştirarak bu bilgiyi üretir ve ispatlarız (ÖA32)."

Örnek ifadede de görüldüğü üzere öğretmen adaylarının bir kısmı, matematiğin esasen aracı olduğu doğa olaylarını anlama gayretini matematiğin amacı gibi ifade etmekle birlikte matematiğin zihnimizin soyut bir ürünü olduğunu da belirtmektedir. Ayrıca adayların çok azı $(f=2)$ matematiksel bilginin birikimsel olarak ilerlediğini de belirtmiştir.

\section{Öğretmen adaylarının bilim - matematik ilişkisi ile ilgili görüşleri}

BMAF'da yer alan ilk dört soru ile öğretmen adaylarının genel anlamda bilim ve matematik ile ilgili algıları belirlenmeye çalışımıştır. Esasen formda yer alan ilk dört soru adayların bilim - matematik ilişkisine dair ipuçları içermekle birlikte formun son üç sorusu ile araştırmanın odağını teşkil eden adayların bilim ile matematik ilişkisi ile ilgili görüşleri ayrıntıları ile belirlenmeye çalışılıştır. Bu bağlamda formun son üç sorusu bir arada ele alınarak analiz edilmiş ve söz konusu sorulara verilen cevapların analiziyle ulaşılan ve adayların bilim - matematik ilişkisi ile ilgili görüşlerini temsil eden kodlar aşağıda Tablo 7'de sunulmuştur.

Tablo 7. Adayların Bilim - Matematik Ilişkisi lle Ilgili Görüşleri

\begin{tabular}{llc}
\hline Kategori & Kod & $\mathrm{n}$ \\
\hline \multirow{3}{*}{ Bilim-Matematik ilişkisi } & Bilim dalı (soyutluğa vurgu) & $14(9)$ \\
& Bilime yardımcı & 10 \\
& Etkileşimli alanlar & 9 \\
& Tüm bilimlerin anası & 5 \\
\hline
\end{tabular}

Tablo 7 incelendiğinde adayların önemli bir kısmının ( $n=14)$ matematiği bir bilim dalı olarak değerlendirdikleri görülmektedir.

"bilim ve matematik birçok yönden birbirine benzer. Ikisi de insanların uzun uğraşları sonucu ortaya çıkar, 
ikisi de hayatt kolaylaştırmaktadır. Ayrıca zaten matematik bir bilimdir...(Ö35)."

Öğretmen adayının örnek ifadesine benzer şekilde adayların bir bölümü, bilim ve matematiği aynı amaca hizmet eden (ki bunun ne ölçüde bilim ve matematiğin amacı olduğu da tartı̧̧ıır) ve zorlu uğraşlar sonucu ortaya çıkan (ki bu zorlu uğraş olmaları belki de onlara değer kazandırmakta bu da değerli ise bilimdir sonucunu doğurmaktadır.) alanlar olduğunu düşünmektedir. Buna ek olarak matematiği bir bilim dalı olarak gören öğretmen adaylarının önemli bir bölümü $(n=9)$ ise matematik ile bilim arasında somut - soyut ayrımını da vurgulamaktadır.

"matematik de bir bilimdir ancak kanıtları soyuttur, zihnimizdedir. Fizik, kimya ve biyoloji genel olarak somut kavramlar içerir matematik ise zihnimizdedir yani soyuttur. Hepsi doğayla ve insanla ilgilenir(ÖA2)."

Örnekte ifadede görüldüğü gibi bu adaylar matematiği bir balım dalı olarak görmekle birlikte fizik, kimya ve biyoloji gibi bilim dalları ile ilgili ayrımlarını somut - soyut kavramları üzerinden yapmaktadırlar. Buna rağmen soyut olan matematiğin doğa ve insan ile ilgilendiği iddiasını da dile getirmektedirler. Adayların önemli bir bölümü ise aşağıdaki örnek ifadelerde de görüleceği üzere matematiği bilim dışı bir alan olmakla birlikte bilime yardımcı $(n=10)$ olarak değerlendirmiştir.

"matematik, bilimlerin dilidir...(ÖA33)."

"matematik, bilimsel bilgilerin (yasaların) oluşmasına yardımcı olur ... (ÖA19)."

Örnek ifadeleri verilen adaylar bilim ile matematik ilişkisini tek yönlü olarak ele almaktadırlar yani sadece matematik bilimin gelişimine yardımcı olmaktadır düşüncesini dile getirmektedirler. Fakat adayların bazıları $(n=9)$ ise aşağıdaki örnek ifadelerde de görüleceği üzere bu ilişkinin karşılıklı fayda prensibi üzerine dizayn edildiğini iddia etmektedir;

"bilim-matematik birbiri ile ilişkili konulardır. Birbirini kapsar diyemem ancak ilgilidirler. Mesela bilim matematikle ya da matematik bilimle ilerliyor ...(ÖA36)."

"bilim ve matematik birbirine söz vermiş eski sevgililerdir (Ö31)."

Bazı öğretmen adayları $(n=5)$ ise bilim - matematik ilişkisine hiyerarşik bir boyut kazandırmış ve matematiği tüm bilimlerin üstünde (anası) olarak ifade etmiştir.

"fizik, kimya, biyoloji tüm bilim dalları matematiğin alt dallarıdır (ÖA29)."

"matematik tüm bilimlerin anasıdır. Şayet matematik olmazsa fizikte kaldırma kuvvetini, kimyada mol hesabını, biyolojide genetik hesaplamaları yapamayız (ÖA15)".

Örnek ifadelerde de görüleceği üzere matematiğin bilim tarafindan çeşitli bağlamlarda kullanılıyor olması adaylarda matematik olmadan bilim olamaz o halde matematik tüm bilimlerin anasıdır algısını oluşturmuştur.

\section{Tartışma ve Sonuç}

Araştırma bulguları incelendiğinde matematik öğretmen adaylarının bilimi tanımlarken bilimin temel amacı olan evreni anlama gayretini vurguladıkları görülmektedir. Ancak adaylar bu vurgunun ötesinde bilime yaşamı kolaylaştırma misyonunu da yükleyerek bilim ile teknoloji arasındaki ilişkiyi net olarak kavrayamadıkları sonucunu ortaya çıkarmışlardır. Bilim ve teknoloji kavramları pek çok çalışmanın konusu olmuştur. Ayvacı ve Er Nas (2010) Fen ve teknoloji öğretmenlerinin \%27'sinin teknoloji ile bilimi birbirine karıştırdıklarını ifade etmektedirler. Benzer durum okulöncesi öğretmen adayları (Turgut, Eş, Bozkurt Altan ve Öztürk Geren, 2016) ve üstün yetenekli ortaokul öğrencileri (Turgut, Öztürk ve Eş, 2017) için de geçerlidir. Eş (2017) ise fen bilimleri öğretmen adayları arasında bilim ile teknolojiyi birbirine karıştıran adaylar olmakla birlikte bu oranın giderek azaldığını ifade etmektedir. Fen öğretmen adaylarında dahi bu karışıklığın olduğu göz önüne alındığında matematik öğretmen adaylarında bu durumun ortaya çıkması beklenen bir sonuç olarak düşünülebilir. Fakat günümüzde bilim ve teknolojinin insan yaşamı üzerindeki direkt ya da dolaylı etkileri değerlendirildiğinde hangi branşta olursa olsun tüm öğretmenlerin bilim ve teknolojinin doğasını anlamaları ve bu iki alan arasındaki ayrımı yapabilmelerinin önemli olduğu düşünülmektedir.

Araştırma bulguları incelendiğinde matematik öğretmen adaylarının önemli bir kısmının bilimsel yöntemi tasvir ederken bilim insanlarının daima izlediği sabit bir adımlar kümesini, onları hiç şaşmadan bilimsel bilgiye ulaştran tek bir hiyerarşik yolu ifade etmeye çalıştıkları, ayrıca bu süreçte teori ve kanun arasında da hiyerarşik bir ilişki kurdukları görülmektedir. Bu tür bir bilimsel yöntem anlayışına sahip olan bireyler kanunları 'ispatlanmış' bilgi olarak göreceklerinden bütün bilimsel bilgilerin değişebilirliğine de inanmazlar (Özden, \& Yenice, 2016). Alan yazında bilimsel kanun ve teorilere ilişkin görüşlerin araştırıldığı çalışmalar incelendiğinde; fen bilgisi ve sınıf öğretmeni adaylarının büyük çoğunluğunun hipotez, teori ve kanun arasında bir hiyerarşinin olup olmadığı ile ilgili yetersiz görüşler belirttikleri (Yenice, 
Özden ve Balcı 2015), sınıf öğretmen adaylarının bazı yanlış anlamalara sahip oldukları (Tatar, Karakuyu \& Tüysüz 2011), fen bilgisi öğretmen adaylarında da bu kavramlar ile ilgili kavram yanılgılarının olduğu (Shiang-Yao, \& Lederman, 2007; Yalçın, Kahraman, Açışı \& Yılmaz, 2010) görülmektedir. Benzer şekilde fizik, kimya, biyoloji öğretmenleri ve ortaöğretim öğrencilerinin de bilimin doğası hakkında benzer kavram yanılgılarına sahip oldukları ifade edilmektedir (Doğan Bora 2005). Sonuç olarak teori ve kanun arasındaki ilişki bilimin doğasının üzerinde önemle durulan boyutlarından birisi (NSTA, 2000) olmasına rağmen, bilimsel kanun ve teorilerin yapısı ve aralarındaki ilişki, farklı branşlardaki öğretmenler, öğretmen adayları ve öğrencilerde en çok karşılaşılan kavram yanılgılarından birisi olarak karşımıza çıkmaktadır (Özden, \& Yenice, 2016). Araştırmanın çalışma grubunu oluşturan matematik öğretmen adaylarının sahip olduğu bu ve benzeri yetersiz ve yanlış düşüncelerin en önemli nedeni olarak, yetiştikleri eğitim sisteminde kullanılan ders kitaplarında ve fen öğretiminde benzeri yanılgıların yaygın bir şekilde kullanılması veya fen öğretim programlarında bilimsel kanun ve teorilerin doğasına yeterince yer verilmemesi gösterilebilir (Aikenhead \& Ryan, 1992; Mccomas, 2002; Özden \& Cavlazoğlu 2015). Matematik öğretmen adayları bilimsel süreci betimlerken deney-gözlem ve kanıtlamaya da vurgu yapmışlardır. Bilimsel süreç ile ilgili görüşleri adayların, bilimi kanıtlanmış ve değişmez gerçeklerden oluşan bir bilme biçimi olarak düşündüklerini, yani bilimsel süreci geleneksel (pozitivist) anlayışla ifade ettiklerini ortaya çıkarmaktadır. İlgili araşttrmalar incelendiğinde benzeri sonuçlara ortaokul düzeyindeki öğrenciler (Turgut, Öztürk, \& Eş, 2017) ve öğretmen adaylarıyla yapılan çalışmalarda da ulaşıldığı görülmektedir (Akerson \& Buzzelli, 2007; Turgut, Eş, Bozkurt Altan ve Öztürk Geren, 2016).

Araştırma bulguları incelendiğinde adayların matematiği tanımlarken sırasıyla en fazla "dil", "bilgi kaynağı" ve "düşünme biçimi" kavramlarını kullandıkları görülmektedir. Alan yazın incelendiğinde Matematiğin bir dil olduğu genelde yaygın kabul gören bir yargı olduğu görülmektedir (Karaçay, 1985; Yıldırım, 1996; King, 1998; Renyi, 2011). Adayların az bir kısmı matematiği tanımlarken "bilim dalı" vurgusu yapmıştı. Bu durum araştrmanın önceki bulguları ile uyum arz etmektedir. Çünkü önceki paragraflarda da ifade edildiği gibi adayların bilim algılarının geleneksel (pozitivist) anlayışa yakın olduğu görülmektedir. Az sayıda da olsa bazı adayların ise matematiği tanımlarken "kültür" ve "oyun" kavramlarını kullandıkları da görülmektedir. Bazı araştırmacılar Matematiğin gündelik yaşam içine sinmiş sıradan ama renkli ve eğlenceli, bir başka deyişle pek tanınmayan yüzünün yaşamı daha zevkli kılacağını iddia etmektedirler (Tepedelenlioğlu, 1983; Nesin, 2001; Sertöz, 2003). Ayrıca tavla, okey gibi zarla oynanan oyunlar "şans" olarak nitelenebilen, önceden bilinemeyen durumlar içerse dahi büyük ölçüde strateji geliştirme, akıl yürütme gibi matematiksel davranışlar gerektirdiği (Nesin, 1989), hatta satranç ve gazetelerin bilmece-bulmaca ek1erinde yer alan mozaik bulmaca, kare karalamaca gibi oyunların da doğrudan doğruya matematik olduğu belirtilmektedir (Umay, 2002a). Öyle ki, Umay (2002b), matematiği insanların kendileri için ürettikleri, üretirken haz duydukları, aslında var olmayan şeyler hakkındaki doğruları ortaya koymayı amaçlayan bir oyun olarak tanımlamaktadır. Öte yandan öğretmen adayları matematiğin amaçları arasında en fazla doğayı anlama gayretini ön plana çıkarmışlardır. Mevcut çalışma grubunda matematiği tanımlarken bilim kavramını kullanan aday sayısı az olmasına rağmen bilimin temel amacının matematik içinde ifade edilmesi adayların bilim ve matematiğin doğası ile ilgili düşüncelerinin çok da berrak olmadığı sonucunu ortaya çıkarmaktadır. Bununla birlikte öğretmen adayları matematiğin amaçları arasında diğer disiplinlere yardımcı olma, kendini geliştirme ve günlük yaşamı kolaylaştırma gibi misyonları da belirtmişlerdir.

Adaylar matematiksel bilgi üretim süreci ile ilgili olarak ise problem çözümü ve ispat kavramlarını vurgulamışlardır. Adayların önemli bir bölümü problemi matematiğe dayandırırken az bir kısmı ise günlük hayata dayandırmakta yani günlük yaşam problemlerine matematiğin çözüm getirdiğini iddia etmektedir. Adayların bir bölümü matematiksel bilgi üretim sürecinin zihinde gerçekleşen soyut yapısına işaret etmektedirler. King (1998) adayların düşüncelerine benzer şekilde matematiksel bilgi üretim sürecinin başlangıcında aksiyom ve tanımların gerçeğin bir yansıması olarak ortaya çıktı̆ını ancak zamanla onlardan çok uzaklarda, düşüncenin açık denizlerinde gerçeklikten uzaklaşıldığını ifade etmektedir.

Araştırmanın odak noktasını teşkil eden matematik öğretmen adaylarının bilim-matematik ilişkisi ile ilgili bulgular değerlendirildiğinde adayların önemli bir bölümünün matematiği bir bilim dalı olarak ifade ettikleri görülmektedir. Bu bulgu ilk etapta araştırmanın diğer bulguları (adayların tanımlarında "bilim" kavramını kullanmamaları vb.) ile çelişkili gibi görünse de esasen adayların yanıtları incelendiğinde çelişki ortadan kalkmaktadır. Çünkü matematiği bilim dalı olarak ifade eden adayların çoğu aynı zamanda matematiğin soyutluğuna da dikkat çekmişlerdir. Adayların bir kısmı ise matematik bilim ilişkisinde matematiği bilime yardımcı olarak ifade ederken bir kısmı ise birbirinden etkilenen iki alan olarak değerlendirmişlerdir. Bunlara ek olarak adayların az bir kısmı ise matematiğin bilim üzerindeki etkisini zirveye çıkararak tüm bilimlerin üstünde görmüş ve bir hiyerarşi ortaya çıkarmışlardır.

Sonuç olarak; matematik öğretmen adaylarının bilim algılarının bazı yanlış anlayışlar üzerine şekillendiği görülmek- 
tedir. Bu durum adayların bilim-matematik ilişkisine de yansımakta ve adayların öğretimini gerçekleştirecekleri matematiğin ne olduğunu ve bilim ile olan ilişkisini tasvir etmede zorluklar yaşamasına neden olmaktadır.

\section{Kaynakça}

AAAS American Association for the Advancement of Science. (1989). Project 2061: Science for all Americans. Washington, DC: Author.

Aikenhead, G. S., \& Ryan, A. G. (1992). The development of a new instrument:'Views on Science-Technology-Society'(VOSTS). Science education, 76(5), 477-491.

Ainsley, R. (1992). Bluff Your Way in Maths. Ravette books.

Akerson, V. L., \& Buzzelli, C. A. (2007). Relationships of preservice early childhood teachers' cultural values, ethical and cognitive developmental levels, and views of nature of science. Journal of Elementary Science Education, 19(1), 15-24.

Akerson, V. L., Buzzelli, C. A., \& Donelly, L. A. (2010). On the nature of teaching nature of science: preservice early childhood teachers' instruction in preschool and elementary settings. Journal of Research in Science Teaching, 47(2), 213-233. doi: 10.1002/tea.20323

Allchin, D. (1996). Points east and west: Acupuncture and comparative philosophy of science. Philosophy of Science, 63, 107-115.

Ayvacı, H. Ş. ve Er Nas, S. (2010). Fen ve teknoloji öğretmenlerinin bilimsel bilginin epistemolojik yapısı hakkındaki temel bilgilerini belirlemeye yönelik bir çalışma. Kastamonu Eğitim Dergisi, 18(3), 691-704.

Berber, N. C. ve Güzel, H. (2009). Fen ve matematik öğretmen adaylarının modellerin bilim ve fendeki rolüne ve amacına ilişkin algıları. Selçuk Üniversitesi Sosyal Bilimler Enstitüsü Dergisi, (21), 87-97.

Bogdan, R.C., \& Biklen, S.K. (1992). Qualitative research for education: A introduction to theory and methods. Boston: Allyn and Bacon. Büyüköztürk, Ş., (2005). “Anket geliştirme.” Türk Eğitim Bilimleri Dergisi 3(2), 133-151.

Creswell, J. W. (2005). Educational research: Planning, conducting and evaluating quantitative and qualitative research. Upper Saddle River, NJ: Pearson Education, Inc.

Creswell, J. W. (2012). Educational research: Planning, conducting and evaluating quantitative and qualitative research. Boston, MA: Pearson Education Inc.

Denzin, N. K. (1978). The research act: A theoretical orientation to sociological methods. New York: McGraw-Hill.

Doğan-Bora, N. (2005). Türkiye'deki orta öğretim fen branşı öğretmen ve öğrencilerinin bilimin doğası hakkında görüşlerinin araştrılması. Doktora Tezi, Gazi Üniversitesi, Ankara.

Eş, H. (2014). Concepts of vegetable and fruit in preschool and elementary education. Journal of Baltic Science Education, 13(5).

Eş, H. (2017). Fen bilimleri öğretmen adaylarııın fen, bilim ve teknoloji kavramları ile ilgili görüşleri. II. International academic research congress. Alanya/Antalya.

Feder, K. (2014). Frauds, myths, and mysteries: science and pseudo-science in archaeology. New York: McGraw-Hill.

Frykholm, J., \& Glasson, G. (2005). Connecting science and mathematics instruction: Pedagogical context knowledge for teachers. School Science and Mathematics 105(3), 127-141.

Francis, L. J., \& Robbins, M. (2007). Belonging without believing: A study in the social significance of Anglican identity and implicit religion among 13-15 year-old males. Implicit Religion, 7(1), 37-54.

Gay, L. R., Mills, G. E., \& Airasian, R. (2006). Educational research: Competencies for analysis and applications (8th ed). Upper Saddle River, NJ: Pearson/Merrill/Prentice Hall.

Hurd, P. D. (1998). Scientific Literacy: New Minds for a Cahanging World. Science Education, 82, 407-416.

Jones, J. P. (2002). Ultrasonic acupuncture and the correlation between acupuncture stimulation and the activation of associated brain cortices using functional magnetic resonance imaging. Bulletin of Science, Technology \& Society, 22(5), 362-370.

Karaçay, T. (1985). "Matematik öğretiminin bugünkü durumu ve değerlendirilmesi". Matematik Öğretimi ve Sorunları, Türk Eğitim Derneği III. Öğretim Toplantssı, Ankara: Yorum Basın-Yayın.

King, J. P. (1998). Matematik Sanatı (5. Basım). TÜBiTAK Popüler Bilim Kitapları 49, Ankara: Nurol Matbaacılık.

Kuhn, T. S. (2006). Bilimsel devrimlerin yapısı (Çeviri: Nilüfer Kuyaş). İstanbul: Kırmııı Yayınları.

Kuryel, B. (2010). Matematiksel Düşüncenin Evrimi-1, Matematik Keşif Mi, Yoksa İcat Mı?, Toplumsal Tarih, s.4-8.

Losh, S. C. \& Nzekwe, B. (2011). Creatures in the classroom: Preservice teacher beliefs about fantastic beasts, magic, extraterrestrials, evolution and creationism. Science \& Education, 20(5-6), 473-489.

Lundström, M. (2007). Students' beliefs in pseudo-science. Paper presented at the European Science Education Research Association (ESERA) conference, Malmö, Sweden.

McComas, A. J. (1996). Skeletal Muscle Form and Function. Champaign, IL: Human Kinetics.

Mertens, D. (1998). Research methods in education and psycohology. New York: SAGE Pub.

Miles, M. B., \& Huberman, A. M. (2015). Nitel veri analizi (2. baskıdan çeviri),(S. Akbaba Altun ve A. Ersoy Çev. Eds). Ankara: Pegem Akademi. National Science Teachers Association [NSTA]. (2000). NSTA position statement on the nature of science. Retrieved January 7, 2018, 
from http://www.nsta.org/about/positions/natureofscience.aspx

Maxwell, J. A. (2005). Qualitative research design: An interactive approach. Thousand Oaks, CA: Sage Publications.

Merriam, S. B. (2013). Nitel araştırma. Desen ve Uygulama Iç̧in Bir Rehber.(Çev. Editörü: Selahattin Turan). Ankara: Nobel Akademik Yayıncilık.

Nesin, A. (1989). Matematik ve Korku (1. Basım) İstanbul: Amaç Yayınları.

Nesin, A. (2001). Matematik ve Oyun (1. Basım, Gözden geçirilmiş). İstanbul: Bilgi Üniversitesi Yayınları.

Özden, B. ve Yenice, N. (2016). Fen Bilgisi Öğretmen Adaylarının Bilimsel Kanun ve Teori Kavramlarına Yönelik Görüşleri: Nitel bir durum çalışması. ilköğretim Online, 15(4).

Özden, M. ve Cavlazoğlu, B. (2015). İlköğretim fen dersi öğretim programlarında bilimin doğası: 2005 ve 2013 programlarının incelenmesi. Eğitimde Nitel Araştırmalar Dergisi, 3(2), 40-65.

Renyi, A. (2011). Matematik Üzerine Diyaloglar. Ankara: Dost Kitabevi.

Sertöz, S. (2003). Matematiğin Aydınlık Dünyası. Ankara: Tübitak Yayınları.

Shiang-Yao, L., \& Lederman, N. G. (2007). Exploring prospective teachers'worldviews and conceptions of nature of science. International Journal of Science Education, 29 (10), 1281- 1307.

Sjölund BH. (2005). Acupuncture or acupuncture?. Pain, 114, 311-312.

Strauss, A., \& Corbin, J. (1998). Basics of qualitative research: techniques and procedures for developing grounded theory. London: Sage. Sönmez, V. ve Alacapınar, F. G., (2016). Örneklendirilmiş Bilimsel Araştırma Yöntemleri, (Genişletilmiş 4. Baskı). Ankara: Anı Yayıncılık.

Şenel, T. ve Aslan, O. (2014). Okul öncesi öğretmen adaylarının bilim ve bilim insanı kavramlarına ilişkin metaforik algıları. Mersin Üniversitesi Eğitim Fakültesi Dergisi 10(2).

Tatar, E., Karakuyu, Y. ve Tüysüz, C. (2011). Sınıf öğretmeni adaylarının bilimin doğası kavramları: Teori, yasa ve hipotez. Mustafa Kemal Üniversitesi Sosyal Bilimler Enstitüsü Dergisi, 8(15), 363-370.

Tepedelenlioğlu, N. (1983). Kim korkar matematikten (1. Baskı) Ankara: Bilim ve Sanat Yayınları.

Toluk, Z. (2003). Üçüncü Uluslararasi Matematik ve Fen Arastirmasi (TIMSS): Matematik Nedir?. Ilköğretim Online, 2(1).

Turgut, H. (2009). Fen bilgisi öğretmen adaylarının bilimsel bilgi ve yöntem algıları. Türk Eğitim Bilimleri Dergisi, 7(1), 165-184.

Turgut, H. (2010). Fen ve teknoloji öğretmen adaylarının bilimsel, sözde-bilimsel ayrımına yönelik algıları. Eğitim ve Bilim $34,154$.

Turgut, H., Eş, H., Bozkurt Altan, E., \& Öztürk Geren, N. (2016). Pre-service pre-school teachers' perceptions of science and pseudo-science. International Online Journal of Educational Sciences, 8(1), 150-169.

Turgut, H., Öztürk, N. ve Eş, H. (2017). Üstün Zekâlı Öğrencilerin Bilim Ve Bilim İnsanı Algısı. Abant İzzet Baysal Üniversitesi Eğitim Fakültesi Dergisi, 17(1).

Umay, A (2002a). Gazetelerin bilmece bulmaca eklerindeki matematik. Bilişim Teknolojileri Işı̆̆ında Eğitim Konferansı ve Sergisi. ODTÜ. Ankara: Semor

Umay, A. (2002b). Öteki matematik. Hacettepe Üniversitesi Eğitim Fakültesi Dergisi, 23.

Yalçın S.A., Kahraman, S., Açışlı, S. ve Yılmaz Z.A. (2010). Fen Bilgisi Öğretmen Adaylarının Bilimin Doğası Konusundaki Görüşlerinin Tespit Edilmesi. Erzincan Üniversitesi Fen Bilimler Enstitüsü Dergisi, 3(2), 181-197.

Yenice, N., Özden, B. ve Balcı, C. (2015). Fen Bilgisi ve Sınıf Öğretmeni Adaylarının Bilimin Doğasına Yönelik Görüşlerinin İncelenmesi. Erzincan Eğitim Fakültesi Dergisi, 17(1), 237-281.

Yıldırım, C. (1996). Matematiksel Düşünme (2. Basım) İstanbul: Remzi Kitabevi.

Yıldırım, C. (2005). Bilim Felsefesi (10.Basım). İstanbul: Remzi Kitabevi. 